\title{
Haitian/Vilokan Idealism, Lakouism, and the Vodou Ethic and the Spirit of Communism
}

\author{
Paul C. Mocombe \\ West Virginia State University \\ The Mocombeian Foundation, Inc. \\ E-mail: pmocombe@mocombeian.com
}

Received: April 11, 2019

Accepted: May 5, 2019

Published: May 10, 2019

doi:10.5296/iss.v7i1.14750

URL: https://doi.org/10.5296/iss.v7i1.14750

\begin{abstract}
The demystification of the Vodou religion or ontology as practiced in Haiti, epistemologically reveals a form of transcendental idealism and realism, Haitian/Vilokan Idealism, which produces a hermeneutical phenomenology, materialism, and an antidialectical process to history enframed by a reciprocal justice as its normative ethics. This work posits and concludes, that Haitian ontology, Vodou/Vilokan, gave rise to its epistemology, Haitian/Vilokan Idealism, which subsequently gave rise to the Vodou Ethic and the spirit of communism and the lakou system as its form of social and system integration, respectively.
\end{abstract}

Keywords: Haitian/Vilokan idealism, Vodou ethic and the spirit of communism, Religiosity, Haitian epistemology, Vodou, Anti-dialectical 


\section{Introduction}

The demystification of the Vodou religion or ontology as practiced in Haiti, epistemologically, reveals a form of transcendental idealism and realism, Haitian/Vilokan Idealism, which produces a hermeneutical phenomenology, materialism, and an antidialectical process to history enframed by a reciprocal justice as its normative ethics. The latter, normative ethic, is invoked by individual social actors to reconcile the noumenal (sacred-ideational) and phenomenal (profane - material) subjective world in order to maintain balance and harmony between the two so that human actors can live freely and happy in a material resource framework where they are the masters of their own existence within the systemicity of Lakou life and the Vodou Ethic and the spirit of communism. This work posits and concludes, that Haitian ontology, Vodou/Vilokan, gave rise to its epistemology, Haitian/Vilokan Idealism, which subsequently gave rise to the Vodou Ethic and the spirit of communism and the lakou system as its form of social and system integration, respectively.

\section{Background of the Problem: Haitian Identity}

Traditional interpretations of the Haitian Revolution, and subsequent to that the constitution of Haitian identity, attempt to understand them, like the constitution of black diasporic and American practical consciousnesses, within the dialectical logic of Hegel's master/slave dialectic (Genovese, 1979; James, 1986; Fick, 1990; Trouillot, 1995; Nicholls, 1979; Du Bois, 2004, 2012; Buck-Morss, 2009; Ramsey, 2014). Concluding that the Haitian Revolution represents a struggle by the enslaved Africans of the island who internalized the liberal norms, values, and rules of their former French masters, for equality of opportunity, recognition, and distribution within and using the metaphysical discourse of their former white slavemasters to convict them of not identifying with their norms, rules, and values as recursively (re) organized and reproduced by blacks. Haitian identity/practical consciousness, as such, was and is a simulacrum, of European (French) practical consciousness and identity, which is universalized and presented as the nature of reality as such. This position, predominantly held by white Westerners, is usually juxtaposed against the postmodern, post-structural, and postcolonial approaches of Haitian and other black bourgeois intellectual elites (i.e., Aimé Césaire), which highlight the hybridity, ambivalence, négritude, syncretism, and créolité, of the Revolution and Haitian consciousness (Genovese, 1979; Fick, 1990; Desmangles, 1992; Trouillot, 1995; Bellegarde-Smith \& Michel, 2006).

Both interpretations, contrary to the position of Haitian intellectuals such as Jacques Roumain (1940) and Jean-Price Mars (1928), who advised the Haitian intelligentsia class to look to the provinces and the peasant classes to constitute Haitian culture, identity, and nation-state, are problematic in that they are ethnocentric and racist. They both overlook the initial African (indigenous) practical consciousness of the majority of the Africans on the island for either the practical consciousness or discourse and discursive practices of the mulatto and petit-bourgeois black elites, Affranchis, looking (because of their interpellation and embourgeoisement) to Europe, Canada, and America for equality of opportunity, recognition, and distribution, or for their (Affranchis) logic of postmodern, post-structural, and postcolonial theories to undermine that African presence in favor of notions of hybridity, 
créolité, négritude, syncretism, intersectionality, double consciousness, and a historical epistemology that traces every aspect of the Haitian Revolution, identity, and consciousness to modernity or a syncretized version of it as highlighted in the work of Susan Buck-Morss (2009).

For me, two forms of system and social integration would structure the material resource framework of Haiti after independence, the Vodou Ethic and the spirit of communism on the one hand, and the Catholic/Protestant Ethic and the spirit of capitalism on the other (Mocombe, 2016). The African majority would be interpellated and subjectified by the enchantment of the world around the former; and their children, young Africans, creole, and free blacks raised or born on the island, although interpellated and subjectified in the former world-view in childhood, many of them would, relationally, marginalize and discriminate against it for the enchantment of the world around the Catholic/Protestant Ethic and the spirit of capitalism of the whites and mulattoes. It is out of the worldview/metaphysics of the former form of system and social integration (the Vodou Ethic and the spirit of communism), and not slavery, that a distinct Haitian Epistemological position can be said to have emerged and developed as the latter (the Catholic/Protestant ethic and the spirit of capitalism) simply seeks to replicate the positivists ideas, concepts, and ideals of the West as prescribed by the NGOs and other imperial institutions, i.e., World Bank, IMF, etc.

As developed and rationalized amongst the Africans of the provinces and mountains of Haiti, Vodou, demystified, produced a Haitian epistemology, Haitian/Vilokan Idealism, which is a transcendental idealist and realist philosophy/epistemology that developed out of the ever-increasing demystification and rationalization of the African (spiritual) worldview (Vilokan/Vodou) of the majority of the inhabitants of the island. That is, it emerges out of the attempt of African people to know and make sense of the world via their Vilokan/Vodou metaphysics; hence its particularism. But it is also a universal project that is compatible and shares certain elements with the scientism of the West. Thus, Haitian Epistemology, Haitian/Vilokan Idealism, is a scientific paradigm, which evolved, liked the scientific project of the West which emerged out of its religiosity, as a result of the ever-increasing demystification, rationalization, and institutionalization (enchantment) of the African worldview which the Africans (their leadership, manbos, oungans, bokos, and elders) of Haiti were able to institutionalize through Vodou, proverbs, herbal medicine, husbandry, dance, rituals, etc. This rationalization and institutionalization project share similar epistemological and methodological processes, i.e., phenomenology, materialism, and antidialectics, as the Western project, especially German Idealism, and is not in its totality distinct from it.

\section{Haitian Epistemology: Haitian/Vilokan Idealism}

Ostensibly, against the contemporary historical epistemology of the West and the Haitian bourgeoisie, which wants to trace the Haitian Revolution, identity, and consciousness to modernity or a syncretism of it, I posit here that an authentic Haitian epistemology emerges out of the ever-increasing rationalization and institutionalization (enchantment) of the physical world around the spiritual belief system, Vilokan/Vodou, of the African people of Haiti. Its science, system and social integration, and epistemology are connected to its 
metaphysics and ontology. Ontologically speaking, within the Haitian metaphysical worldview, Vilokan/Vodou, the world is a unitary (energy) material world created out of Bondye. The world is a creation of a good God, Bondye Bon, which created the world and humanity out of itself composed of two intersecting spheres, the profane (the phenomenal world) and sacred (noumenal/Vilokanic, mirrored world of the profane). Embedded in that pantheistic material world are concepts, lwa yo in Haitian metaphysics, from the parallel mirrored (Vilokanic) world, that humanity can ascertain via experience and the structure of its being, form of understanding and sensibility (dreams, reason and rationality, extrasensory perceptions), to help make sense of their experience and live in the world, which is Bondye, and therefore sacred, as they (via their nanm) seek perfection and reunification (reintegration) with God, the energy force/source.

That is to say, it, Bondye, provided humanity with objects, concepts, ideas, ideals, and practices, i.e., lwa of Vodou, proverbs, rituals, dance, geometry, knowledge of herbal medicine, trades, and skills, by which they ought to know, interpret, and make sense of the external (phenomenal profane) world and live in it comfortably. These transcendentally real objects, concepts, ideas, ideals, and practices can either be known through dreams, divinations, experience or rationality, and becomes the structure (once reified and institutionalized as proverbs, husbandry, dance, rituals, institutions, etc.), form of sensibility and understanding, through which humanity come to know, hold beliefs and truth-claims. So Bondye, a powerful energy force that always existed created the world and humanity out of itself using four hundred and one transcendentally real concepts (God and four-hundred lwa), ideas, and ideals (geometric principles, mathematics, etc.). Humanity and the world around it is an aggregation of bondye's material energy, the energy of God, which constitutes its existence. In humanity this existence is composed of three distinct aggregation of energy ( $t i$ bon anj; gwo bon anj; ko, the body), all of which are material stuff, which constitute our nanm (souls) where personality, truth-claims, knowledge, and beliefs are deposited, via dreams, revelations, extrasensory perceptions, divinations, experience, reason, the energy source of a God as manifested via a lwa, and can be examined and explored as the synthetic a priori of the human agent.

For humanity to constitute its existence and be in the world according to the will of God or Bondye, in other words, transcendentally real concepts stemming from God's will (the mirrored world of the profane, Vilokan) are embedded in the material world, which is God, and can be ascertain and embodied by humanity via their constituted being as a material being with extrasensory perceptions, reason and rationality, and or through experience. As these transcendentally real concepts are ascertain, they are constituted and institutionalized, and passed on through humanity via priests/priestesses and early ancestors who institutionalized (reify)/ institutionalize them in the natural world via religious ceremonies, dance, rituals, herbal medicine, trades, concepts, and proverbs. These trades, ideals, proverbs, and or concepts are truisms, mechanisms to ascertain and constitute knowledge, which although they are deduced from the constituted make-up (i.e., consciousness) of the human being, in Haitian metaphysics they are attributed to God and the ancestors who institutionalized (reified) them in order to be applied in the material world so that their 
descendants can live freely in the world, satisfy their needs, be happy, and achieve perfection in order to reunite with God after their sixteen life cycles.

The Haitian Epistemological position that would emerge out of this metaphysical worldview, Vodou, of the African people of Haiti and their form of system and social integration is a strong form of Kantian transcendental idealism and realism, which would be institutionalized throughout the provinces and mountains of the island (Desmangles, 1992; Mocombe, 2016).

Kantian transcendental idealism "attempts to combine empirical realism, preserving the ordinary independence and reality of objects of the world, with transcendental idealism, which allows that in some sense the objects have their ordinary properties (their causal powers, and their spatial and temporal position) only because our minds are so structured that these are the categories we impose upon the manifold of experience" (Blackburn, 2008, p. 356). Haitian epistemological transcendental idealism, Haitian Idealism or Vilokan Idealism, is a form of transcendental idealism in the Kantian sense in that it attempts to synthesize empiricism, idealism (rationalism), and realism via synthetic a priori concepts/ideals the Haitians believe can be applied not only to the phenomenal but also the noumenal (Vilokanic) world in order to ascertain the latter's transcendentally real absolute knowledges they call, lwa, gods/goddesses (401 concepts, ideas, and ideals represented as gods/goddesses), of Vilokan/Vodou. So like Kant, Haitian epistemological transcendental idealism, holds on to analytic truths, truths of reasons or definitions, as outlined in their proverbs (pwoveb); a posteriori truth, truths of experience or experiments, also embedded in their proverbs, geometry (veves), rituals, magic, sorcery, and herbal medicine; and synthetic a priori concepts (categories in Kantian epistemology supplemented with trances, dream-states, extrasensory perceptions), truths stemming from the form of the understanding and sensibility of the mind and apparatuses of experience embedded not only in their proverbs and Vodou rituals, beliefs, and magic, but also their understanding of trances, dream-states, and extrasensory perceptions as categories of the mind applicable to the noumenal or Vilokanic realm where transcendental real concepts, lwa yo, exist (as Platonic forms) which they must ascertain in order to live life happily in the phenomenal world without masters or owners of production. The latter (trances, dream-states, and extrasensory perceptions) they believe, in other words, can be applied to the noumenal or Vilokanic world in order to know gods/goddesses, lwa yo, which are immutable/absolute concepts, ideas, and ideals God has created and imposed upon and in the material world, from the mirrored world of the earth (Vilokan), which the people, who embody these concepts, ideas, and ideals, should utilize to recursively reorganize and reproduce their being-in-and-as-the-world in order to achieve perfection over sixteen life cycles (Desmangles, 1992; Beauvoir, 2006; Author, 2016). Hence, unlike Kantian transcendental idealism, which removes God out of the equation via the categories, which imposes the order we see in the phenomenal world, Haitian epistemological transcendental idealism and realism, Haitian/Vilokan Idealism, holds on to the concept of God, supernatural, and the paranormal to continue to make sense of the plural tensions between the natural (material) world, i.e., the world of phenomenon, and the world as such, ideational, noumena, i.e., the supernatural and paranormal world, transcendental real world, which is knowable as truth-claims, knowledge, and beliefs, through dreams, divinations, revelations, experience, 
reason and rationality, and the synthetic a priori, for pure (development of science, i.e., herbal medicine, etc.) and practical reason (i.e., morals and values). Thus Haitian/Vilokan Idealism, unlike Kantian Transcendental Idealism, implies that the objects, concepts, ideals, ideas, etc., of the (ideational) noumenal world are transcendentally real and the form of sensibilities and understandings, which include dream states, trances, and extrasensory perceptions are other categories of the understanding, which can be applied beyond the phenomenal world, where the objects are really subjective (interpretive) ideas, in order to ascertain the nature of the absolute concepts of the Vilokanic/noumenal world in order to achieve balance and harmony with it in the phenomenal.

Within this pantheistic (Spinozaian) conception of the multiverse and material world, knowledge, truth-claims, and beliefs arise from transcendentally real ideational concepts (lwa yo) of bondye/God as embedded in the earth's mirrored world (Vilokan) and gets deposited in our nanm (souls) intuitively, in dreams, revelations, divinations, extrasensory perceptions, reason, rituals, and or experiences which in turn constitutes and structures the form of the understanding of our minds and bodies (senses) so that we can experience the material world according to our developmental track over sixteen reincarnated life cycles (Beauvoir, 2006; Author, 2016). The human being recursively (re) organize and reproduce these (Platonic) transcendentally real ideational concepts as their practical consciousness in the phenomenal material world not always in its absolute form as defined noumenally (the sacred mirrored world of Vilokan), but according to their level of learning, development, capacity for knowledge, and modality, i.e., the way they know more profoundly-kinesthetically, visually, etc.

As defined, Haitian epistemology is an epistemological transcendental idealism and realism, Haitian Idealism or Vilokan Idealism, which posits that both phenomena (the profane world) and noumena (its mirror image where wisdom, ideals, and ancestors reside) are knowable through experience and the form of human sensibility and understanding (the categories of Kantian epistemology supplemented with, dreams, divinations, extrasensory perceptions, and trance states), which stems from the energy force of a God, which constitutes our nanm (a material thing), and used to recursively organize and reproduce our being-in-and-as-the-world.

So on top of the twelve Kantian schematized categories of the understanding, divided into four groups of three (1. The axioms of intuition, i.e., unity, plurality, and totality; 2. The anticipations of perception, i.e., reality, limitation, and negation; 3. The postulates of empirical thought, i.e., necessary, actual, and possible; 4. The analogies, i.e., substance, cause, and reciprocity), necessary for experience by making objective space and time possible, Vilokanic/Haitian idealism adds dream states, trances, and extrasensory perceptions as a fifth group of three to make known the concepts, lwa, of the Vilokanic world knowable so that human actors can achieve balance between the phenomenal world and the former (Vilokanic/noumenal).

For Kant experience requires both the senses, the a priori forms of sensibility, i.e., space and time, and the understanding, i.e. the twelve categories. A unified consciousness (not a self or 
the Cartesian "I"), which is a structural feature of experience necessary to provide the unity to our experience, what Kant calls, "the transcendental unity of apperception," rule-governed and connected by the categories, experiences real objects that we perceive and exist independently of our perception of them. Thus, the spatio-temporal objects are necessarily relative to and subject to the a priori forms of experience, i.e., forms of sensibility and the understanding. In this sense, Kant does away with the noumenal world of absolutes, which is unknowable as the independent objects are phenomenal, relative to the a priori forms of experience. Unlike Kant, however, Haitian Idealism posits that the nanm, which provides unity to our experiences is a material thing, a Cartesian material "I" composed of three distinct entities (sometimes more as Haitian metaphysics suggests that a fourth entity, lwa met tet, may constitute the nanm of serviteurs in order to guide them in their decision-making) that are also tied to the natural world and can be manipulated in life as well as death. On top of it's a priori forms of sensibility and Kantian categories are dream-states, trances, and extrasensory perceptions, which allows the nanm to have access to the world of Vilokan/noumenal world where we can perceive the things that are phenomenal, relative to our a priori forms of experience, as they are in-themselves in order to achieve balance between the world as it appears to us and how it ought to be so that we can live abundantly as individual masters of our own destiny.

Hence Haitian epistemological transcendental idealism (Haitian Idealism, Vilokanism, Vodouism, or Vilokan Idealism) and realism is not only natural, but supernatural and paranormal to the extent that it supplements the synthetic a priori concepts Kant attributes to the categories of the mind with divinations, revelations, dream states, and extrasensory perceptions in order to ascertain the absolute (transcendentally real) concepts, ideals, ideas, etc., (lwa) of God as embedded in the noumenal (Vilokanic) world. Moreover, it posits that these absolute lwa yo, transcendentally real concepts, ideas, ideals, etc., are part of the noumenal world (sacred world of Vilokan), which is not a plural world as plurality, in keeping with the logic of Arthur Schopenhauer, belongs to the world of phenomenon, and can eventually be known by extrasensory perceptions, human reason, understanding, and experience. However, in the human sphere the world of phenomenon and its plurality is a result of the different levels of development (reason, experience, capacity, and modality) of the consciousness of the human subjects (not all humans develop their form of sensibilities and understanding at the same rate or in the same life cycle) where the concepts of lwa yo are embedded and embodied and recursively organized and reproduced as the practical consciousness of the human actor. Albeit humanity is reincarnated until they have ascertained all of the true concepts of the unitary world, which can be done so through experience and a priori, and will seize to exist (will seize to experience reincarnation) once they do so.

Haitian Idealism and Realism as such indicates a condition of transcendentally real absolutes on the one hand as it pertains to the Vilokanic or noumenal world; and relativity in our notions of objects and reality on the other as it pertains to the transcendentally ideal phenomenal world. In terms of the latter, the phenomenal world, in other words, is simply the world of plurality constituted by imperfect beings, anti-dialectically (constantly fighting against the praxis of others for their own understanding and praxis), living through their 
aggregated material bodies and imperfections according to their level of learning, development, capacity for knowledge, and modality, i.e., the way they know more profoundly-kinesthetically, visually, etc., within the Vodou Ethic and the spirit of communism and the lakou system.

\section{Conclusion: The Vodou Ethic and the Spirit of Communism and the Lakou System}

Hence Haitian/Vilokan Idealism is phenomenological, material, and antidialectical in the sense that the emphasis is on the things (concepts, ideas, ideals) of consciousness as revealed to, and interpreted by, human individuals (via the form of sensibility and understanding) from the noumenal world of Vilokan. These things (concepts, ideas, and ideals) of consciousness they in-turn recursively reorganize and reproduce as their practical consciousness, antidialectically, against the interpretive practical consciousnesses of others within a normative ethic of reciprocal justice of the socioeconomic/political structure of the Lakou as organized in a material resource framework. As Laurent Du Bois $(2004,2012)$ highlights, the lakou is a community of people and houses organized and gathered around a common yard under the directions of a oungan (Vodou priest), manbo (Vodou priestess), or family elder that promoted and promotes an egalitarian existence rooted in the Vodou religion and ancestor worship, land ownership arrangements, and working the soil. Within the lakou system, each individual or nuclear family owned/own their own land, through which they provided/provide for basic necessities by growing food and raising livestock for their own consumption and for sale in local markets. They also grew and grow export crops, such as coffee, in order to buy imported consumer goods such as clothes and tools. The lakou thus divided power in a way that allowed rural residents to live and work as they wished (through land and garden ownership to provide for their own subsistence), while preventing the consolidation of wealth, and therefore control and inhibitor of equality, in the hands of any one person within the community through a set of customs and secret societies of the Vodou religion that regulate(d) land ownership, land transfers, family relationships, and community affairs. Communal assistance and exchange, via food sharing, harvesting, house building, religious life, and ancestral worship, under the leadership of women also characterized and characterizes lakou life. In essence, the purpose of lakou life is to promote total liberty and equality, via land ownership and self-sufficiency, for all without distinctions and economic differentiation. It is out of the Vodou Ethic (the form of social integration) that the lakou system would emerge as its form of system integration. Hence, the systemicity of Lakouism, and its libertarian communal living, is not a reaction to, or resilience against, the Protestant Ethic and the spirit of capitalism of whites and the Affranchis. It is the by-product of an alternative form of social integration, the Vodou Ethic and the spirit of communism.

The evolution and rationalization of the phenomenology, materialism, and antidialectics of Haitian/Vilokan Idealism becomes institutionalized and reified via its form of system and social integration called the Lakou and the Vodou Ethic and the spirit of communism, respectively, where human actors are allowed to exercise their practical consciousness as they understand them from the noumenal world. So unlike the antidialectic of Nietzsche which promotes an existential phenomenology against system and social integration, i.e., the dialectics and holism of Hegel, the antidialectic of Haitian/Vilokan idealism, via its Lakou 


\section{NI Macrothink}

Issues in Social Science

ISSN 2329-521X

2019, Vol. 7, No. 1

system promotes a social phenomenology wherein individuals, depending on their spiritual court, intellectual capacity, developmental stage, etc., attempt to constitute their existence based on their understanding of the concepts of the noumenal world in order to maintain balance and harmony between nature, the individual, and their social interactions as they provide for their material well-being via agricultural production and trade within the systemicity of lakou life and the Vodou Ethic and the spirit of communism. Difference or freedom of expression and egalitarianism become the contents of their form of system and social integration so that Being or human existential existence can achieve perfection, embodying the concepts of the noumenal world, and harmony over sixteen life-cycles.

\section{References}

Althusser, L. (2001). Lenin and Philosophy and Other Essays. New York: Monthly Review Press.

Buck-Morss, S. (2009). Hegel, Haiti, and Universal History. Pittsburgh: University of Pittsburgh Press. https://doi.org/10.2307/j.ctt7zwbgz

Cohen, J. (2002). Protestantism and Capitalism: The Mechanisms of Influence. New York: Aldine de Gruyter.

Crothers, C. (2003). Technical Advances in General Sociological Theory: The Potential Contribution of Post-Structurationist Sociology. Perspectives, 26(3), 3-6.

Du Bois, L. (2012). Haiti: The Afterschocks of History. New York: Metropolitan Books.

Du Bois, L.(2004). Avengers of the New World. Massachusetts: Harvard University Press.

Fanon, F. (1967). Black Skin, White Masks (Charles Lam Markmann, Trans.). New York: Grove Press.

Fraser, N. (1997). Justice Interruptus: Critical Reflections on the "Postsocialist" Condition. New York \& London: Routledge.

Gartman, D. (2002). Bourdieu's Theory of Cultural Change: Explication, Application, Critique. Sociological Theory, 20(2), 255-277. https://doi.org/10.1111/1467-9558.00162

Giddens, A. (1984). The Constitution of Society: Outline of the Theory of Structuration. Cambridge: Polity Press.

Gutman, H. (1976). The Black Family in Slavery and Freedom 1750-1925. New York: Pantheon Books.

Habermas, J. (1984). The Theory of Communicative Action: Reason and the Rationalization of Society (Vol. 1, Thomas McCarthy, Trans.). Boston: Beacon Press.

Habermas, J. (1987). The Theory of Communicative Action: Lifeworld and System: A Critique of Functionalist Reason (Vol. 2, Thomas McCarthy, Trans.). Boston: Beacon Press.

Holloway, J. E. (1990b). The Origins of African-American Culture. In J. Holloway (Ed.), Africanisms in American Culture (pp. 19-33). Bloomington and Indianapolis: Indiana 


\section{Mll Macrothink}

University Press.

Holloway, J. E. (Ed.) (1990a). Africanisms in American Culture. Bloomington and Indianapolis: Indiana University Press.

Hudson, K., \& Andrea, C. (2005). The Dark Side of the Protestant Ethic: A Comparative Analysis of Welfare Reform. Sociological Theory, 23(1), 1-24. https://doi.org/10.1111/j.0735-2751.2005.00240.x

James, C. L. R. (1986). The Black Jacobins: Toussaint L' Ouverture and the San Domingo Revolution. Vintage.

Karenga, Maulana (1993). Introduction to Black Studies. California: The University of Sankore Press.

Lukács, G. (1971). History and Class Consciousness: Studies in Marxist Dialectics (Rodney Livingstone, Trans.). Cambridge, Massachusetts: The MIT Press.

Lukács, G. (2000). A Defence of History and Class Consciousness: Tailism and the Dialectic (Esther Leslie, Trans.). London and New York: Verso.

Marx, K. (1992). Capital: A Critique of Political Economy (Vol. 1, Samuel Moore and Edward Aveling, Trans.). New York: International Publishers.

Marx, K.(1998). The German Ideology. New York: Prometheus Books.

Mocombe, P. C. (2016). The Vodou Ethic and the Spirit of Communism: The Practical Consciousness of the African People of Haiti. Maryland: University Press of America.

Ortner, S. (1984). Theory in Anthropology Since the Sixties. Comparative Studies in Society and History, 26, 126-66. https://doi.org/10.1017/S0010417500010811

Patterson, O. (1982). Slavery and Social Death: A Comparative Study. Cambridge, Massachusetts: Harvard University Press.

Ramsey, K. (2011). The Spirits and the Law: Vodou and Power in Haiti. Chicago: University of Chicago Press. https://doi.org/10.7208/chicago/9780226703817.001.0001

Rubin, V. (Ed.) (1960). Caribbean Studies: A Symposium. Seattle: University of Washington Press.

Smith, M. G. (1960). The African Heritage in the Caribbean. In V. Rubin (Ed.), Caribbean Studies: A Symposium (pp. 34-46). Seattle: University of Washington Press.

Weber, M. (1958). The Protestant Ethic and the Spirit of Capitalism (Talcott Parsons, Trans.). New York: Charles Scribner's Sons. 


\section{Copyright Disclaimer}

Copyright for this article is retained by the author(s), with first publication rights granted to the journal.

This is an open-access article distributed under the terms and conditions of the Creative Commons Attribution license (http://creativecommons.org/licenses/by/3.0/). 